\title{
Cloning and Characterization of the Pectate Lyase III Gene of Erwinia carotovora Er
}

\author{
Aruto Yoshida, Miho Izuta, ${ }^{*}$ Kazutoshi Ito,** \\ Yoshiyuki Kamı and Kazuo IzaKI \\ Department of Agricultural Chemistry, Faculty of Agriculture, \\ Tohoku University, Sendai 981, Japan \\ Received August 8, 1990
}

\begin{abstract}
A pectate lyase gene III (pel III) of Erwinia carotovora Er was cloned. The gene was expressed independently of a vector promoter in both $E$. carotovora $\mathrm{Er}$ and Escherichia coli. The pel III product was largely excreted in the culture medium of $E$. carotovora Er, while the product was only exported to the periplasmic space and was not excreted in the medium of $E$, coli. Nucleotide sequence analysis of pel III disclosed an open reading frame of $1,122 \mathrm{bp}$ encoding a protein of 374 amino acids. The deduced amino acid sequence contained the $\mathrm{N}$-terminal 30 amino acid sequence from the purified pectate lyase III (PL III) indicating the presence of a 22-amino-acid signal peptide. A putative ribosome-binding site was found to be $9 \mathrm{bp}$ upstream of the start codon. The location of pel III was about $5.6 \mathrm{~kb}$ downstream of pel 1 . The PL III showed $80 \%$ homology in the amino acid sequence with the PL I of E. carotovora Er. ${ }^{9 \text { ) }}$
\end{abstract}

Erwinia carotovora and Erwinia chrysanthemi are phytopathogenic bacteria that cause soft-rot diseases in many plant species. ${ }^{2}$ Their pathogenicity is due to their ability to produce several extracellular enzymes including pectinases, cellulases and proteases. ${ }^{3)}$ These extracelullar enzymes attack plant cell walls and membrane components and lead to plant tissue maceration. Among pectinases, pectate lyase (PL) has been extensively studied and seems to be one of the most important determinants of the pathogenicity. ${ }^{4)}$

$E$. carotovora produces two to four isozymes of PL ${ }^{5)}$ while E. chrysanthemi produces at least five PLs. ${ }^{6)}$ To study the regulation of $\mathrm{PL}$ production and the role of PL isozymes in pathogenecity, several laboratories have isolated genes of PL (pels). ${ }^{8,18,24,29-34)}$ In softrot Erwinia, the production of PLs is induced by polygalacturonate and its metabolites, and repressed by glucose.

Previous work in our laboratory indicated that $E$. carotovora Er secreted at least three different PLs (PL I, PL II, and PL III). PL I and PL II were purified and characterized by Sugiura et al., ${ }^{7)}$ and pel I was cloned and sequenced. ${ }^{8,9)}$ To identify the whole structures of the pel genes, we tried to clone other pel genes using a part of pel I as a probe. In this report, we describe the cloning and the characterization of pel III.

\section{Materials and Methods}

Materials. Restriction endonucleases, sequencing reagents, and other DNA modifying enzymes were purchased from Takara Shuzo Co, Ltd., Kyoto and Toyobo Co., Ltd., Osaka. All ${ }^{32}$ P-labeled nucleotides were obtained from Amersham Co., Ltd., Buckinghamshire, U.K.

Bacterial strains, plasmids, and phage. The bacterial strains, plasmids, and phage used in this study are listed in Table I. E. coli $\mathrm{HB} 101$ was used for the construction of the genomic library. E. coli JM 109 was used as the host of recombinant plasmids. $E$. coli MV1184 was used for the preparation of single-stranded template DNA for sequen-

* Present address: Central Research Institute, Nihon Roche Co., Kamakura, Kanagawa 247, Japan.

** Present address: Plant Bioengineering Research Laboratories, Sapporo Breweries Ltd., Kizaki Nitta, Gunma 370-03, Japan. 
Table I. Bacterial Strains, Plasmids, and Phage

\begin{tabular}{|c|c|c|}
\hline Strain and plasmid & Genotype or description & Source or reference \\
\hline \multicolumn{3}{|l|}{ Escherichia coli } \\
\hline HB101 & 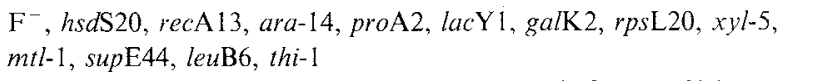 & 14 \\
\hline JM 109 & 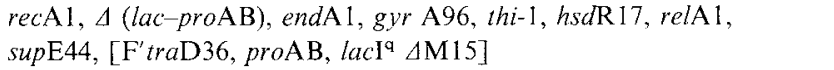 & 10 \\
\hline MV1184 & 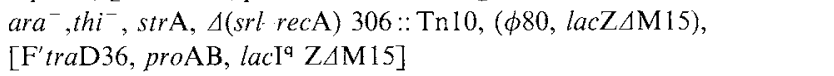 & 11 \\
\hline \multicolumn{3}{|l|}{ Erwinia carotovora } \\
\hline Er (IAM 1068) & wild type & 1 \\
\hline \multicolumn{3}{|l|}{ Plasmids } \\
\hline $\begin{array}{l}\text { pUC118 and } \\
\text { pUC119 }\end{array}$ & Cloning plasmid & 11 \\
\hline pBR329 & Cloning plasmid & 12 \\
\hline $\mathrm{pNN} 3$ & $\begin{array}{l}4.1 \mathrm{~kb} \text { Hind III }- \text { Pst I fragment containing pelIII, cloned in } \\
\text { pUC119 }\end{array}$ & This study \\
\hline $\mathrm{pNN} 3 \mathrm{~B}$ & $\begin{array}{l}4.1 \mathrm{~kb} \text { HindIII-BamHI fragment of pNN3 cloned into the same } \\
\text { site of pBR } 329\end{array}$ & This study \\
\hline $\mathrm{pNNl}$ & $8.7 \mathrm{~kb}$ Eco RI fragment containing Pell and pelX, cloned in pBR329 & 8 \\
\hline pNN101 & $\begin{array}{l}5.1 \mathrm{~kb} E c o \mathrm{RI}-\text { HindIII fragment of pNN1 cloned into the same site } \\
\text { of pBR329 }\end{array}$ & 8 \\
\hline pNNIl & $\begin{array}{l}1.9 \mathrm{~kb} \text { HindIII-Pst } \mathrm{I} \text { fragment of pNN1 cloned into the same site of } \\
\text { pUC1 } 19\end{array}$ & This study \\
\hline \multicolumn{3}{|l|}{ Phage } \\
\hline M13 K07 & M13 helper phage & 11 \\
\hline
\end{tabular}

cing.

Media and growth conditions. E. carotovora Er was usually grown aerobically in LB medium ${ }^{14)}$ at $30^{\circ} \mathrm{C}$. E. coli strains were grown aerobically in LB medium or $2 \times \mathrm{YT}$ medium ${ }^{13)}$ at $37^{\circ} \mathrm{C}$. If required, $50 \mu \mathrm{g} / \mathrm{ml}$ of ampicillin and $70 \mu \mathrm{g} / \mathrm{ml}$ of kanamycin were added to the medium.

Southern and colony hybridization. Chromosomal DNA from $E$. carotovora Er was prepared by the method of Rodriguez et al. ${ }^{15}$ After digestion of DNA with several restriction endonucleases, the fragments were resolved in an agarose gel and transferred to a nylon membrane for Southern blot analysis.

$E$. coli colonies were grwon on nylon membranes, and filters were treated by the instruction of the maker (Amersham Co., Ltd.).

As hybridization probes, two kinds of DNA fragments were used. One was the $0.4-\mathrm{kb}$ Pst I-HpaII fragment of pNNI (probe I) and the other was the 0.3-kb Pst I-EcoRI fragment of pNNl (probe II) (Fig. 1A). These probes were labeled with $\left[\gamma_{-}{ }^{32} \mathrm{P}\right] \mathrm{ATP}$ using T4 polynucleotide kinase after dephosphorylation. Hybridization was done at $65^{\circ} \mathrm{C}$ with washing according to the manufacturer's standard conditions (Amersham Co., Ltd.).

DNA sequencing. DNA was sequenced by the dideoxy chain termination method of Sanger et al. ${ }^{16)}$ DNA fragments from pNN3 were subcloned in pUC118 or pUC119, and the single-stranded template DNA was prepared by infection of $E$. coli MV1184 with the M13 K07 helper phage. Sequencing reactions were done according to the protocols supplied with the M13 Sequencing Kit or 7-DEAZA Sequencing Kit (Takara Shuzo Co., Ltd.).

Construction of $p N N 3$. The $1.9-\mathrm{kb}$ HindIII-Pst $\mathrm{I}$ fragment obtained by digestion of pNNI was cloned into the HindIII and PstI sites of pUC119, and the resulting plasmid was designated $\mathrm{pNN} 11$. On the other hand, $E$. carotovora Er chromosomal DNA was completely digested with PstI and the DNA was size-fractionated by agarose gel electrophoresis. DNA fragments of $2.0-2.5 \mathrm{~kb}$ were ligated to the $P s t 1$ site of pNN 1 1 , and the resulting plasmids were used to transform $E$. coli $\mathrm{HB} 101$. Ampicillin-resistant colonies were screened by both colony hybridization with probe II and plate assay for PL production.

Measurements of enzyme activities. PL activity in fluid was measured by monitoring the increase of optical density at $235 \mathrm{~nm}$ as described previously. ${ }^{17)}$

A plate assay to screen the $E$. coli colonies for $\mathrm{PL}$ production was done on $\mathrm{YC}$ agar plates containing $0.7 \%$ sodium polygalacturonate and $50 \mu \mathrm{g} / \mathrm{ml}$ ampicillin. ${ }^{18,19)}$ The clones were grown on the plate and lysed by exposing the colonies to chloroform vapor. After leaving the plates 
A

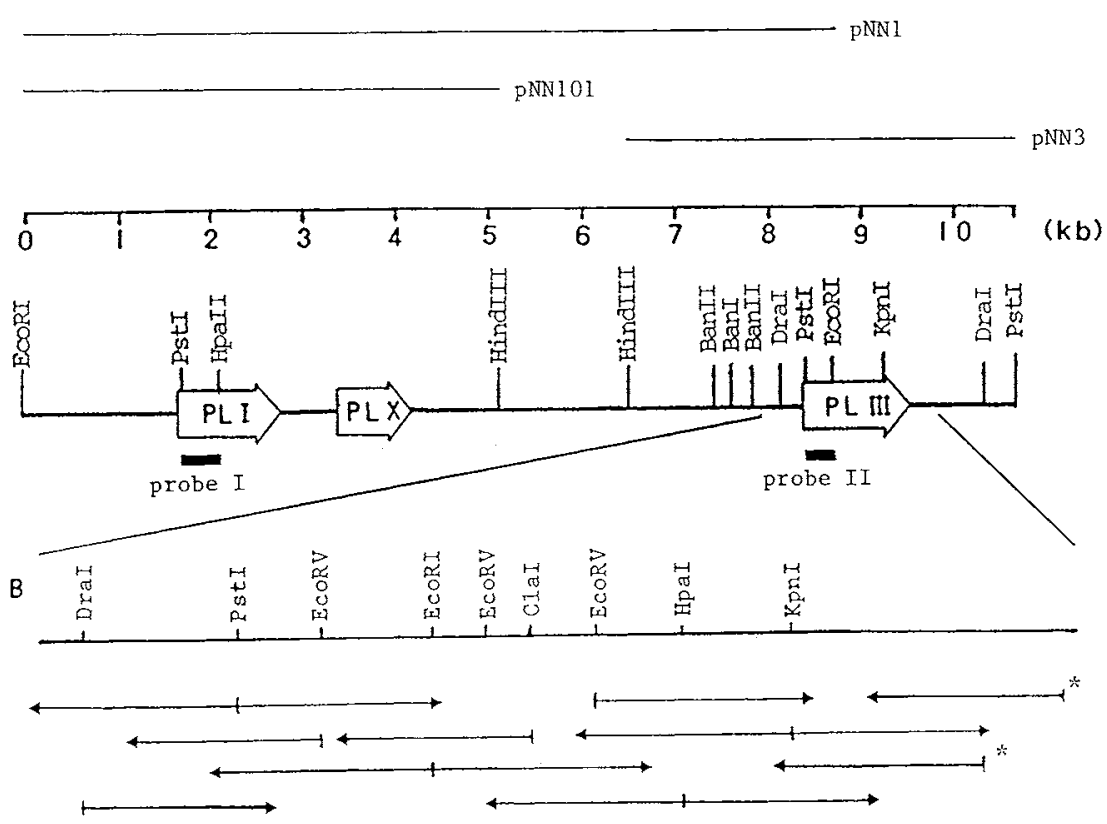

Fig. 1. (A) Restriction Map of the Cloned pel I-pel III Region.

Thin lines represent the cloned fragments in different pBR329 or pUCl19 derivatives. Thick lines indicate the fragments of probe I and probe II, respectively.

(B) Sequencing Strategy for pel III.

Arrows mark the extent and the direction of nucleotide sequence runs. Two BAL31 nuclease-deleted clones are marked with asterisks.

at $30^{\circ} \mathrm{C}$ for more than $2 \mathrm{hr}$, positive clones were detected by flooding the plates with $1 \mathrm{M} \mathrm{CaCl}$.

Activities of $\beta$-lactamase and $\beta$-galactosidase were assayed by the methods of Sawai et al. ${ }^{20}$ and Miller, ${ }^{21)}$ respectively.

Fractionation of extracellular, periplasmic, and cytoplasmic PLs in E. coli cells. Fractionation of PL was done by the method of Cornelis et al. ${ }^{22)} E$. coli cells were grown in LB medium, harvested at the early stationary phase, and washed twice with $10 \mathrm{~mm}$ Tris- $\mathrm{HCl}$ buffer $(\mathrm{pH} 7.5)$ containing $25 \%$ sucrose. The washed cells were suspended in the same buffer containing $25 \%$ sucrose and $1 \mathrm{~mm}$ EDTA, and the suspension was gently shaken for $10 \mathrm{~min}$ at room temperature. After centrifugation at 3,000 $\times g$ for $10 \mathrm{~min}$, the cells were quickly and vigorously suspended in ice-cold water. The suspension was further shaken for $10 \mathrm{~min}$ at $4^{\circ} \mathrm{C}$ and centrifuged at $8,000 \times g$ for $10 \mathrm{~min}$. The supernatant contained the periplasmic enzymes of the cells. The precipitated cells suspended in $10 \mathrm{~mm}$ Tris- $\mathrm{HCl}$ buffer (pH 7.5) and disrupted with a French pressure cell $\left(500-600 \mathrm{~kg} / \mathrm{cm}^{2}\right)$. The cytoplasmic fraction was obtained from the disrupted cell fraction by centrifugation at $22,000 \times g$ for $10 \mathrm{~min}$.

\section{Results}

Cloning of pel III

Previous work from our laboratory indicated that $E$. carotovora Er excreted a large amount of PL I and PL II in the culture medium, while only a small amount of PL III was produced. PL I and PL II were purified by Sugiura et al., ${ }^{7)}$ but PL III has not been purified because of its small quantity. The $\mathrm{N}$-terminal 10 amino acids of PL I and PL II were identical. ${ }^{7)}$ To search for pel II and pel III, Southern blot analysis of pNN1 using probe I, which encoded the N-terminal region of PL I was done. As shown in Fig. 2A, two fragments were detected in EcoRI and HindIII digests of pNN1 (lane 2). It was expected that the $2.2-\mathrm{kb} H$ indIII-EcoRI fragment might contain pel II or pel III, because the 5.1-kb EcoRI-HindIII fragment included pel I (Fig. 1A). Furthermore, the $0.3-\mathrm{kb}$ Pst $\mathrm{I}-E c o \mathrm{RI}$ fragment in the $2.2-\mathrm{kb}$ 

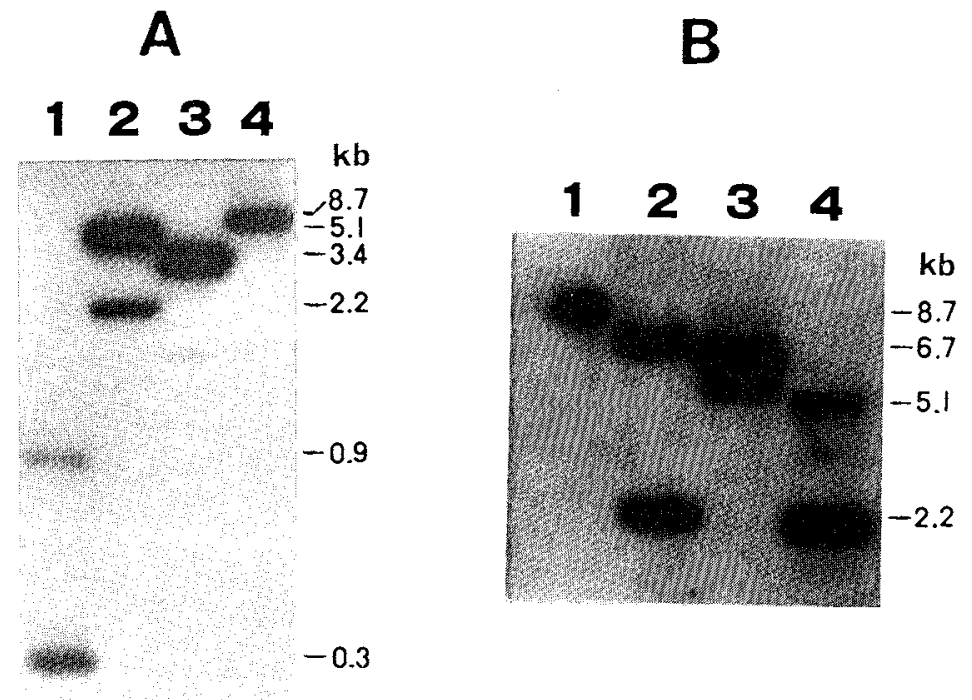

Fig. 2. Autoradiograms of Southern Blot Analysis.

(A) Detection of the DNA region homologus to pell with probe I. Lanes: 1, BanII plus PstI digests of the 2.2-kb HindIII-EcoRI fragment in pNN1; 2, EcoRI plus HindIII digests of pNN1; 3, EcoRI, HindIII plus Pst I digests of pNN10I; 4, EcoRI digests of pNN1. Approximate sizes in kb are indicated on the right. (B) Detection of the DNA fragment containing the $0.3-\mathrm{kb}$ Pst $-E c o$ RI region with probe II. Chromosomal DNA was digested with following restriction endonucleases. Lanes: 1, EcoRI; 2, Pst 1; 3, HindIII; 4, EcoRI plus HindIII. Approximate sizes in $\mathrm{kb}$ are indicated on the right.

HindIII-EcoRI region strongly hybridized with the probe (lane 1). An analysis of the nucleotide sequence of the $0.3-\mathrm{kb}$ Pst I-EcoRI fragment found an open reading frame of $303 \mathrm{bp}$ encoding 101 amino acid residues. Its amino acid sequence had a high homology with that of PL I. And the N-terminal 10 amino acids were also detected in the $0.3-\mathrm{kb}$ Pst $\mathrm{I}-E c o \mathrm{RI}$ fragment. Since this region was a part of the gene due to EcoRI cutting (Fig. 1A), Southern blot analysis for the chromosomal DNA was done using probe II to obtain recombinants covering the whole gene. Probe II hybridized to both a $6.7-\mathrm{kb} P s t \mathrm{I}-P$ st I fragment and a 2.2-kb Pst I-PstI fragment (Fig. 2B). From the restriction map of $8.7-\mathrm{kb} \quad E c o \mathrm{RI}-E c o \mathrm{RI}$ fragment shown in Fig. 1A, the 2.2-kb Pst I$P_{s t} \mathrm{I}$ fragment was concluded to contain the 0.3-kb Pst I-EcoRI region.

To construct the pel gene, E. carotovora Er chromosomal DNA was digested with Pst I completely and DNA fragments of $2.0-2.5 \mathrm{~kb}$ were ligated to the PstI site of pNN11 as described in Materials and Methods.
Among 1,200 clones tested, 38 clones were found to hybridize with probe II, and 17 clones among the 38 positive clones showed PL activities by the plate assay. Some of these 17 clones had an identical recombinant plasmid containing a $4.1-\mathrm{kb}$ segment of chromosomal DNA and it was designated pNN3. A restriction map of pNN3 is shown in Fig. 1A.

\section{Identification of PL isozyme cloned in pNN3}

$E$. carotovora $\mathrm{Er}$ was transformed with pNN3 by the method of Reverchon. ${ }^{23)}$ Extracellular PLs produced by E. carotovora Er were separated and characterized by hydroxyapatite column chromatography as described previously. ${ }^{9)}$ Elution profiles of PL activities in culture fluids of $E$. carotovora $\mathrm{Er}$ strains harboring $\mathrm{pNN} 3$ and without $\mathrm{pNN} 3$ in hydroxyapatite column chromatography are shown in Fig. 3. E. carotovora Er harboring pNN3 raised the level of PL III activity about 50-fold in comparison with the host strain, but it didn't affect levels of PL I and PL II activities. From these results, the pel gene encoded in 
pNN3 was pel III alone. When the cell extract of $E$. coli $\mathrm{HB} 101$ harboring $\mathrm{pNN} 3$ was analyzed by the same method, the elution point of the PL activity was approximately the same as PL III in the concentration of potassium phosphate buffer (data not shown).

Expression of pel III and cellular localization of $P L I I I$ in $E$. coli

A $2.2-\mathrm{kb}$ Dral-DraI fragment containing the $203 \mathrm{bp}$ sequence upstream of the ShineDalgarno sequence and the pel III structural gene was cloned into the SmaI site of pUC119.

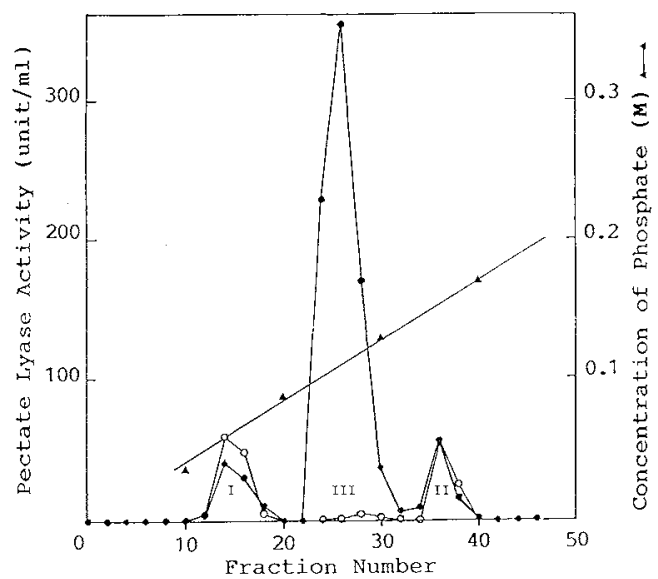

Fig. 3. Elution Profiles of Pectate Lyases on Hydroxyapatite Column Chromatography.

The activities of E. carotovora $\mathrm{Er}(O)$ and $E$. carotovora Er harboring pNN3 (O) were analyzed.
Two recombinant plasmids carrying the insert in the same or the opposite direction to the lac promoter were obtained. Both of the E. coli HB101 transformants carrying the these two kinds of plasmids had PL III activity. These results indicate that the 203-bp sequence upstream of the Shine-Dalgarno sequence contains a promoter which is recognized by $E$. coli (data not shown).

In our preliminary experiments, the PL activity was detected in the culture fluid at the stationary phase of $E$. coli HB101 harboring pNN3, and at the same time, a large amount of $\beta$-lactamase activity was also found. These phenomena seemed to come from the result of overproduction of these enzymes according to the high copy number of the vector pUC119. Then a 4.1-kb HindIII-BamHI fragment of pNN3 was ligated to HindIII and BamHI sites of pBR329, and this plasmid was designated pNN3B. Unlike $E$. coli HB101 harboring $\mathrm{pNN} 3$, little $\beta$-lactamase activity was found in the culture fluid of $E$. coli $\mathrm{HB} 101$ harboring pNN3B throughout its growth phase (data not shown).

E. coli $\mathrm{HB} 101$ harboring $\mathrm{pNN} 101$, pNN3B, or pBR329 was grown until the early stationary phase. The cells were harvested by centrifugation and washed, and the cellular fractions were prepared as described in Materials and Methods. $\beta$-Lactamase (a periplasmic marker

Table II. Localization of Pectate Lyase and Other Enzymes in E. coli HB101 CaRrYing pNN101, pNN3B OR pBR329

\begin{tabular}{|c|c|c|c|c|}
\hline Enzymes & Plasmid & $\begin{array}{l}\text { Extracellular activity } \\
\qquad(\mathrm{U})\end{array}$ & $\begin{array}{l}\text { Periplasmic activity } \\
\text { (U) }\end{array}$ & $\begin{array}{c}\text { Cytoplasmic activity } \\
\text { (U) }\end{array}$ \\
\hline \multirow{3}{*}{ Pectate lyase } & pNN101 & $0.0(0.0)^{a}$ & $0.0(0.0)$ & $185.3(100.0)$ \\
\hline & pNN3B & $0.0(0.0)$ & $730.0(31.5)$ & $1584.4(68.5)$ \\
\hline & pBR329 & 0.0 & 0.0 & 0.0 \\
\hline \multirow{3}{*}{$\beta$-Lactamase } & pNN101 & $87.0(8.1)$ & $911.5(84.9)$ & $75.4(7.0)$ \\
\hline & pNN3B & $52.3(8.0)$ & $551.1(83.8)$ & $54.2(8.2)$ \\
\hline & pBR329 & $191.1(7.9)$ & $2120.4(87.6)$ & $109.0(4.5)$ \\
\hline \multirow{3}{*}{$\beta$-Galactosidase } & pNN 101 & $0.00(0.0)$ & $0.072(3.8)$ & $1.81(96.2)$ \\
\hline & pNN3B & $0.00(0.0)$ & $0.067(3.5)$ & $1.86(96.5)$ \\
\hline & pBR329 & $0.00(0.0)$ & $0.064(4.5)$ & $1.37(95.5)$ \\
\hline
\end{tabular}

a Values in parentheses indicate percent distribution of the enzyme in each strain. 
enzyme) and $\beta$-galactosidase (a cytoplasmic marker enzyme) activities in different cellular compartments were measured (Table II). About $30 \%$ of PL III activity was found in the periplasm, while no PL III activity was detected in the culture fluid. On the other hand, most of $\beta$-lactamase activity and $\beta$-galactosidase activity were found in the periplasm and the cytoplasm, respectively. It appeared, therefore, that the PL III was exported to the periplasm by a specific transport mechanism.
Nucleotide sequence of pel III

Restriction endonuclease-digested subclones and BAL31 nuclease-deleted subclones of pNN3 were used for DNA sequencing. The overall sequencing strategy is shown in Fig. 1B. The sequence obtained covered a 1,415-bp region, and an open reading frame was found as shown in Fig. 4. The open reading frame encodes 374 amino acid residues starting from the initiation codon at bases 218 to 220 . The sequence AGGAG, 9 bases upstream of the

$\begin{array}{ccccccc}10 & 20 & 30 & 40 & 50 & 60 & 70 \\ \text { TTIAAAATAGATACTTATTAAGCATTGATGTTTCCATCATTATTCATGAGATATATTTAATACCTAAATATTGAATTATTTTTCTTTTAT }\end{array}$ $\begin{array}{ccccccccc}100 & 110 & 120 & 130 & 140 & 150 & 160 & 170\end{array}$ GGTAAGACTTATCTTGGTTTTCAATAAACCTTGATTTCATT'TTTATTGAAACACCAAAATAATATAATCTGGGTTATGTGGAACAT'TAAT

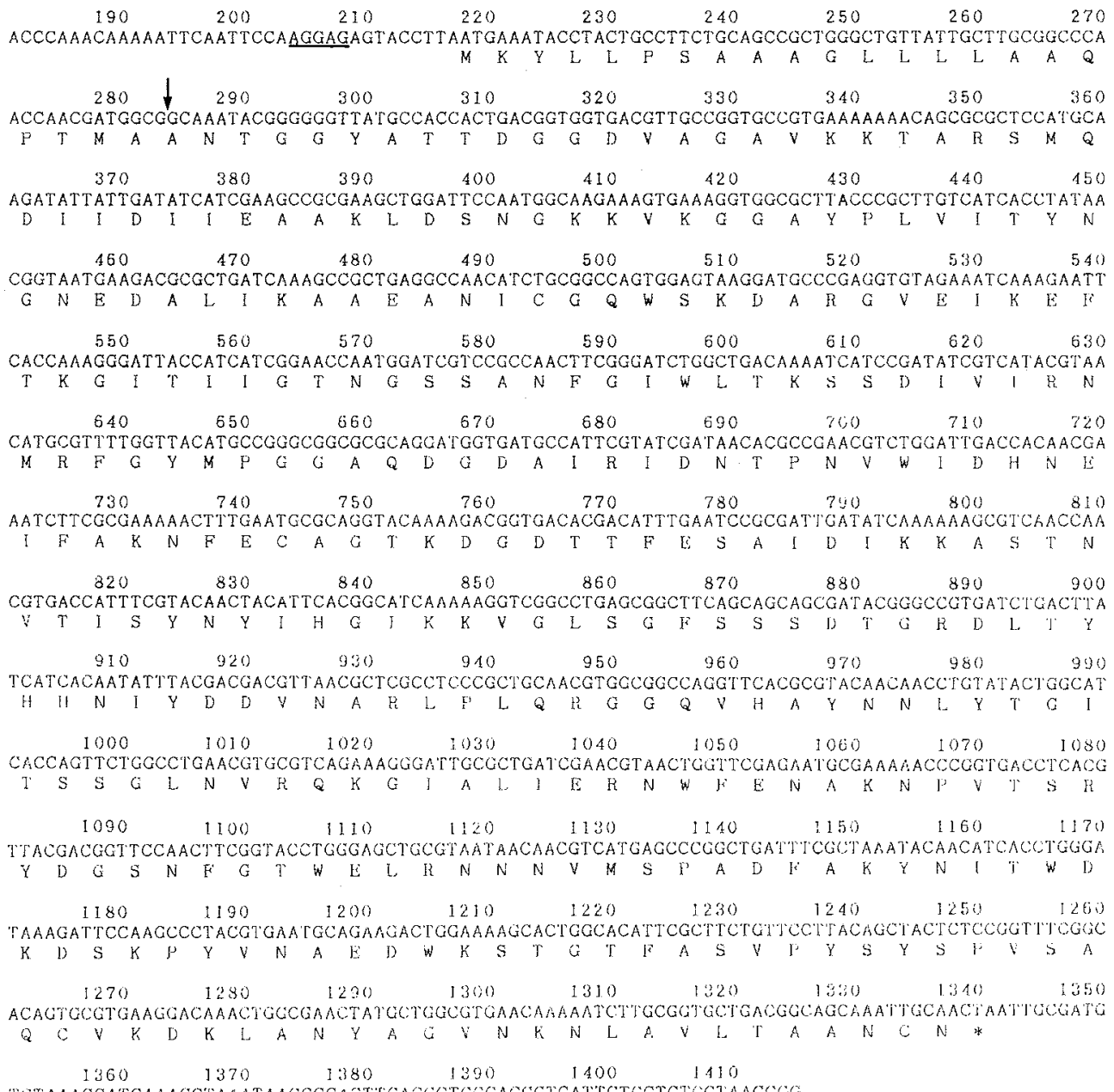

TOTAAACCATGAAAGGIAAATAAGGGACT TCAGCOTCCGACCCTCATTGTCCTGTGCTAACCGG

Fig. 4. Nucleotide Sequence of the pel III Region and the Predicted Amino Acid Sequence of the Encoded PL III.

A possible ribosome-binding site is underlined. The signal peptide processing site is indicated by an arrow. 
initiation codon, is likely to be a ribosomebinding site. The amino acid sequence from Ala23 to Asp52 matched exactly with the $\mathrm{N}$-terminal 30 amino acid sequence of PL III purified from the culture medium of $E$. carotovora Er harboring pNN3. ${ }^{36)}$ Therefore, it appeared that PL III had a 22-amino-acid signal peptide, which is typical for prokaryotic proteins both in size and the distribution of hydrophobic and hydrophilic amino acid residues. The amino acid sequence from Try 289 to Thr296 was also identical to that of a tryptic polypeptide of the purified PL III. ${ }^{36)}$

The calculated molecular weight of the precursor form and the processed form of PL III were 40,480 and 38,253 , respectively, and the calculated molecular weight of the processed form corresponded generally to the molecular weight of 39,500 estimated by SDS-PAGE of the purified PL III. ${ }^{36)}$

\section{Discussion}

Although more than two PLs of $E$. carotovora are secreted into the culture medium, the regulatory mechanism of each PL production and the roles of individual PLs in pathogenecity are not clear. Recently, to characterize an individual PL, several pel genes were cloned. $8,24,29,34)$

We previously reported the cloning of pel I of $E$. carotovora $\mathrm{Er}$ and its nucleotide sequence. $^{8,9)}$ Southern blot analysis of $\mathrm{pNN} 1$, which contained pel $\mathrm{I}$, suggested that another pel gene might be about $5.6 \mathrm{~kb}$ downstream of pel I. As expected, a pel gene was found on a 4.1-kb HindIII-PstI fragment. This pel gene was identified as pel III from the analysis of the culture supernatant of $E$. carotovora $\mathrm{Er}$ containing the newly cloned pel gene by hydroxyapatite column chromatography. The pel III was about $5.6 \mathrm{~kb}$ downstream of pel I, and both pel I and pel III had individual transcription units in the same direction. We previously found a pel $\mathrm{X}$ gene $0.6 \mathrm{~kb}$ downstream of pel I. It was highly homologus to pel $\mathrm{I}$, but its function is not clear. Since there is about $2.2 \mathrm{~kb}$ between pel $\mathrm{X}$ and pel III, another pel gene might be found in this region. Actually, a $0.9-\mathrm{kb}$ HindIII-BanII region was hybridized with probe II in Southern blot analysis (Fig. 2A).

Lei et al. cloned three pels which are a tandem cluster in the same transcriptional direction in E. carotovora $\mathrm{EC}^{24)}$ and sequenced the nucleotides of pel A and pel B. ${ }^{25,26)}$ The comparison of nucleotide sequences of pel III with those of pel A or pel B suggested that pel III might correspond to pel C. Recently, Hinton et al. also cloned and sequenced pel $\mathrm{C}$ of $E$. carotovora SCRI193, ${ }^{34)}$ and there was $98.7 \%$ homology between PL C and PL III in the amino acid sequeunce. Moreover, the comparison in the nucleotide sequence between $1812 \mathrm{bp}$ of pel C and $1415 \mathrm{bp}$ of pel III showed $93 \%$ homology, and the homology extended not only to structural genes but also to $5^{\prime}$ - and $3^{\prime}$-noncoding regions. We have purified PL III, and we showed that the actual signal peptide cleavage site of PL III is different from that of PL C deduced from the nucleotide sequence. Purification and characterization of PL III are described in the accompanying paper. ${ }^{36}$ )

The nucleotide sequence of pel III was compared with that of pel $\mathrm{I}$, and considerable homology between them was detected. Both PL I and PL III seemed to start from a methionine residue in the same position, but PL III had 8 extra amino acids compared with PL I in the C-terminal portion. The processed PL I and PL III contained 345 and 352 amino acids, respectively. The homology between them was $80 \%$.

pel III was highly expressed in $E$. coli independent of the lac promoter, while pel I was only poorly expressed (Table II). But cloned pel I was expressed in E. carotovora $\mathrm{Er}$ as well as cloned pel III (data not shown). Since several sequences which were very similar to the E. coli promoter were found in $5^{\prime}$ noncoding $217 \mathrm{bp}$ region of pel III, these sequences might be recognized in E. coli (Fig. 4). And it is possible that the true promoter sequence of $E$. carotovora is a little different from that of $E$. coli.

The comparison of the $\mathrm{N}$-terminal amino 
acid sequence of purified PL III with the deduced amino acid sequence from the nucleotide sequence of pel III suggested that PL III had a 22-amino-acid signal peptide. ${ }^{36}$ This signal peptide was the same length as that of PL I. ${ }^{9)}$ It was reported that the pel I product was accumulated in the cytoplasm of $E$. coli. ${ }^{9)}$ The pel III product was not secreted into the culture fluid, either, but excreted into the periplasmic space. The pel I product might be accumulated in the cytoplasmic space according to the low expression of pel I in $E$. coli. Andro et al. reported that one or more steps of secretion process might exsist in $E$. chrysanthemi using the Out ${ }^{-}$mutant, which was defective in the secretion of pectinases and cellulases. ${ }^{35)}$ E. carotovora also seems to have a complex secretion mechanism which is not explained clearly by the signal hypothesis and requires some other factors.

\section{References}

1) M. Hayashibe and T. Watanabe, Agric. Biol. Chem., 26, 82 (1962).

2) M. C. M. Pelombelon and A. Kelman, Ann. Rev. Phytopathol., 18, 361 (1980).

3) A. Kotoujansky, Ann. Rev. Phytopathol, 25, 405 (1987).

4) A. Collmer and N. T. Keen, Ann. Rev. Phytopathol., 24, 383 (1986).

5) J. L. Reid and A. Collmer, Appl. Environ. Microbiol., 52, 305 (1986)

6) F. V. Gijsegem, J. Gen. Microbiol., 132, 617 (1986).

7) J. Sugiura, M. Yasuda, S. Kamimiya, K. Izaki and H. Takahashi, J. Gen. Appl. Microbiol., 30, 167 (1984).

8) N. Nikaido, T. Naganuma, K. Ito, K. Izaki and H. Takahashi, J. Gen. Appl. Microbiol., 31, 293 (1985).

9) K. Ito, R. Kobayashi, N. Nikaido and K. Izaki, Agric. Biol. Chem., 52, 479 (1988).

10) C. Yanish-Perron, J. Vieira and J. Messing, Gene, 33, 103 (1985).

11) J. Vieira and J. Messing, Methods Enzymol., 153, 3 (1987)

12) L. Covarrubias and F. Bolivar, Gene, 17, 79 (1982).

13) L. G. Davis, M. D. Dibner and J. F. Battey, "Method in Molecular Biology," Elsevier Science Publishing Co., Inc., New York, 1986, p. 250.

14) T. Maniatis, E. F. Fritsh and J. Sambrook, "Molecular Cloning," Cold Spring Harbor Laboratory, New York, 1982, p. 68.

15) R. L. Rodriguez and C. Tait, "Recombinant DNA Techniques, An Introduction," Addison-Wesley Publishing Company, Massachusetts, 1986, pp.45 46.

16) F. Sanger, Science, 214, 1205 (1981).

17) S. Kamimiya, Y. Itoh, K. Izaki and H. Takahashi, Agric. Biol. Chem., 41, 975 (1977).

18) N. T. Keen, D. Dahlbeck, B. Staskawicz and W Belser, J: Bacteriol., 159, 825 (1984).

19) S. Manulis, D. Y. Kobayashi and N. T. Keen, $J$. Bacteriol., 170, 1825 (1988).

20) T. Sawai, I. Takahashi and S. Yamagishi, Antimicrob. Agents Chemother., 13, 910 (1978).

21) J. H. Miller, "Experiments in Molecular Genetics," Cold Spring Harbor, New York, 1972, pp. 352 355 .

22) P. Cornelis, C. Digneffe and K. Willemot, Mol. Gen. Genet., 186, 507 (1982).

23) S. Reverchon and J. Robert-Baudouy, Biochimie, 67, 253 (1985).

24) S. P. Lei, J. C. Lin, L. Hefferman and G. Wilcox, Gene, 35, 63 (1985).

25) S. P. Lei, H. C. Lin, S. S. Wang and G. Wilcox, Gene, 62, $159(1988)$

26) S. P. Lei, H. C. Lin, S. S. Wang, J. Callaway and G. Wilcox, J. Bacteriol., 169, 4379 (1987)

27) N. T. Keen and S. Tamaki, J. Bacteriol,, 168, 595 (1986)

28) S. J. Tamaki, S. Gold, M. Robeson, S. Manulis and N. T. Keen, J. Bacteriol., 170, 3468 (1988).

29) R. T. Zink and A. K. Chaterjee, Appl. Environ. Microbiol., 49, 714 (1985).

30) A. Collmer, C. Schoedel, D. L. Roeder, J. L. Ried and J. F. Rissler, J. Bacteriol., 161, 913 (1985).

31) A. Kotoujansky, A. Diolez, M. Boccara, Y. Bertheau, T. Andro and A. Coleno, EMBO J., 4, 781 (1985).

32) S. Reverchon, N. Hugouvieux-Cotte-Pattat and $J$. Robert-Baudouy, Gene, 35, 121 (1985).

33) F. V. Gijsegem, A. Toussaint and E. Schoonejans, EMBO J., 4, 787 (1985).

34) J. C. D. Hinton, J. M. Sidebotham, D. R. Gill and G. P. C. Salmond, Mol. Microbiol., 3, 1785 (1989).

35) T. Andro, J. P. Chambost, A. Kotoujansky, J. Cattaneo, Y. Bertheau, F. Barras, F. V. Gijsegem and A. Coleno, J. Bacteriol., 160, 1199 (1984).

36) A. Yoshida, K. Ito, Y. Kamio and K. Izaki, Agric. Biol. Chem., 55, 601 (1991). 